\title{
Evaluation of Quality Parameters and Shelf Life of Thai Pork Scratching "Kaeb Moo"
}

\author{
Thanapon Kitpot, ${ }^{1}$ Sujinda Sriwattana, ${ }^{1,2}$ Sergio Angeli, ${ }^{3}$ and Prodpran Thakeow $\mathbb{D}^{1,2}$ \\ ${ }^{1}$ Division of Product Development Technology, Faculty of Agro-industry, Chiang Mai University, 155 Moo 2, Mae-Hea, Mueang, \\ Chiang Mai 50100, Thailand \\ ${ }^{2}$ Sensory Evaluation and Consumer Testing Unit, Faculty of Agro-Industry, Chiang Mai University, Chiang Mai 50100, Thailand \\ ${ }^{3}$ Faculty of Science and Technology, Free University of Bozen-Bolzano, Piazza Università 1, 39100 Bolzano, Italy \\ Correspondence should be addressed to Prodpran Thakeow; prodpran.t@cmu.ac.th
}

Received 25 October 2018; Revised 16 January 2019; Accepted 3 February 2019; Published 27 February 2019

Academic Editor: Antonio J. Signes-Pastor

Copyright (c) 2019 Thanapon Kitpot et al. This is an open access article distributed under the Creative Commons Attribution License, which permits unrestricted use, distribution, and reproduction in any medium, provided the original work is properly cited.

\begin{abstract}
Fried foods are one of the most favorite products worldwide because of their typical flavor and crispness. In Thailand, one of the most popular traditional foods is "Kaeb Moo," a fried pork rind product typical of the Northern Region and widely consumed across the whole country. In this research, we monitored the quality change of Kaeb Moo during storage for 1 month and predicted the consumers' acceptance measuring texture, moisture contents, malondialdehyde (MDA) and hexanal contents, and peroxide values (PV) of frying oil, as this fried product undergoes a rapid hydrolysis and rancidity. The analyses were done on three types of Kaeb Moo: the first type was prepared in the lab using high-quality products, while the other two types were purchased from local markets in Thailand. It was found that rancidity variation during storage strongly depends on the frying process and product quality, as in 31 days the hexanal content only doubled (225\%) in Kaeb Moo type 1, while reached 542\% and 962\%, in Kaeb Moo type 2 and type 3, respectively. The increase of rancidity was observed even if the peroxide values of frying oil were under the national regulation. At the end of shelf life, the properties of Kaeb Moo samples from predicting equations were as follows: $3.67-6.01 \%$ moisture contents, $0.396-0.503 \mu \mathrm{g} / \mathrm{g}$ MDA contents, $0.342-0.481 \mathrm{mg} / \mathrm{kg}$ hexanal contents, $50.01-60.08 \mathrm{~kg} \cdot \mathrm{s}$ linear distances (crispness), $36.01-48.83 \mathrm{~mm}$ rancid rating, and $43.72-45.38 \mathrm{~mm}$ crispness rating.
\end{abstract}

\section{Introduction}

Fried foods are one of the most favorite products for consumers because of their typical flavor and texture. These special properties are developed by the frying process, in which raw materials are cooked under hot oil. Generally, the frying temperatures range from $150^{\circ} \mathrm{C}$ to $190^{\circ} \mathrm{C}$; however, higher temperatures of $190^{\circ} \mathrm{C}$ to $205^{\circ} \mathrm{C}$ are also used $[1,2]$. Even though there have been many reports on the direct and indirect health effects of fried food consumption, for example, obesity, diabetes, hypertension, and cardiovascular disease, during last years, the consumption quantity of fried food has continuously increased [3-5].

In Thailand, one of the most popular traditional foods is "Kaeb Moo." It is a typical product of the Northern Region and widely consumed across the whole country by Thai people as well as by tourists. Kaeb Moo can be consumed alone as snack or can be served as a side dish of Northern style Thai foods [6]. The economic value of Kaeb Moo production in the north of Thailand was estimated to be about 3,000 million Baht (ca. 100 million US\$) in 2011 [7]. It is produced by deep frying of seasoned pork rind by smallmedium entrepreneurs or by local producers at fresh and street markets; the latter Kaeb Moo is freshly fried and sold directly in the markets without product quality control [8]. However, Kaeb Moo may undergo a fast rancidity process and sometimes consumers experience a dislike taste of rancidity just after purchasing. Rancidity of Kaeb Moo could be linked to many factors such as the quality of raw material, the preparation process (prior to frying), the quality of frying oil, the packaging, and the storage conditions. Inappropriate storage conditions with high temperature, moisture and 
light, and low oil quality could lead to fast quality deterioration [9].

Oxidative rancidity is the major problem of fried food, occurring through lipid oxidation of unsaturated fatty acids which react with oxygen through a free radical mechanism [10]. An obvious result of this reaction is the formation of rancid odor. There are many classes of compounds reported as major volatiles from oxidized pork muscle and pork rind. However, the most abundant volatiles are aldehydes, for example, pentanal, hexanal, heptanal, and nonanal $[8,11]$. Among those aldehydes, hexanal is the most important compound contributing to rancid odor, and it is considered as a marker for rancidity in fried products together with thiobarbituric acid reactive substances (TBARS), acid value (AV), and peroxide values (PV) [12]. Although consumers are merely concerned about rancidity and texture of the fried product, there are other chemicals not contributing to the rancid odor but formed during rancidity, like 4-hydroxy-2-nonenal (4$\mathrm{HNE}$ ) and malondialdehyde (MDA). Remarkably, 4-HNE and MDA are found to be involved in carcinogenesis [13-15].

As Kaeb Moo is highly consumed by Thai people as well as tourists, there is a rising concern about potential health effect of Kaeb Moo. However, so far there were no studies conducted on monitoring of Kaeb Moo quality during storage in correlation with sensory analysis. Therefore, in this research, we intended to evaluate the physical, chemical, and sensory qualities of Kaeb Moo from different productions during storage, to create correlation between the quality and consumers' acceptance, and to find out a key indicator of Kaeb Moo product quality.

\section{Materials and Methods}

2.1. Preparation of Kaeb Moo and Frying Oil Samples. Three types of Kaeb Moo without subcutaneous fat layer were used in this research. Type 1 (T1) was produced using an electrical frying machine (FR1265, Fritel, Belgium). Pork skin was deep fried in refined palm oil (Morakot Industrial Public Co., Ltd., Thailand) at $205^{\circ} \mathrm{C}$ for $2 \mathrm{~min}$. The other two types (T2 and T3) were purchased just after frying from two local producers in fresh street markets of Chiang Mai province, Thailand. Among the local Kaeb Moo producers of the Chiang Mai city, we firstly considered those well known by consumers, being long time in the market and producing at least $50 \mathrm{~kg} /$ day of Kaeb Moo. Among them, two producers were selected randomly. The samples T2 and T3 were of $3 \mathrm{~kg}$ each. Then, each sample was subdivided into 200 polypropylene bags filled with $15 \mathrm{~g}$ of Kaeb Moo. T1 sample was prepared by the same preparation procedure. All samples were stored in an incubator (MIR-553, Sunyo, Japan) at $25 \pm 1^{\circ} \mathrm{C}$ through the experimental period of 31 days. The oil used for T2 and T3 sample production was also refined palm oil. Samples of $100 \mathrm{ml}$ were taken three times, considering different lots of Kaeb Moo production both from local producers and from in-lab production.

\subsection{Analysis of Physical and Chemical Properties of Kaeb Moo.} Physical and chemical properties of Kaeb Moo including texture, moisture contents, malondialdehyde (MDA) contents, and hexanal contents were determined during storage. In addition to these properties, peroxide values (PV) of frying oil of the three samples were also evaluated.

2.2.1. Moisture Content. Moisture content was analyzed according the AOAC method [16]. In brief, for each replicate, the sample of approximately $3.0 \mathrm{~g}$ was crushed, homogenized, and then placed into a moisture can which was previously dried and weighed. Then, the three replicates were placed in an oven (Memmert UNE 400, Memmert $\mathrm{GmbH}$, Germany) and dried at $105^{\circ} \mathrm{C}$ until the constant weights were obtained. The moisture content of each sample was calculated in terms of loss weight percentage.

2.2.2. Texture Analysis. Hardness and crispness of Kaeb Moo samples were measured using a texture analyzer (TAXT plus, Stable Micro Systems Ltd., Surrey, UK) equipped with an Ottawa cell extrusion as described in [8]. For hardness analysis, there were 15 replicates for each sample. Maximum force was recorded as the resistance to breakage. For crispness analysis, there were 30 replicates for each sample. The averages of maximum force and linear distance were reported in $\mathrm{kg}_{f}$ and $\mathrm{kg}_{f} \cdot \mathrm{s}$, respectively.

2.2.3. Malondialdehyde Content. MDA content was analyzed according to the thiobarbituric acid reactive substances (TBARS) method as described in Miller [17]. Five grams of each sample were extracted using $44 \mathrm{~mL}$ of $10 \%$ trichloroacetic acid (AR-grade, Merck, Germany) in $0.02 \mathrm{M}$ phosphoric acid $\left(\mathrm{H}_{3} \mathrm{PO}_{4}, \mathrm{AR}\right.$-grade, Merck) with $1 \mathrm{~mL}$ of $0.2 \mathrm{mg} / \mathrm{mL}$ of butylated hydroxy toluene (BHT, AR-grade, Fluka, Switzerland) and then filtered. Then, the sample was subjected to react with thiobarbituric acid (AR-grade, Merck, Germany) and kept in darkness for $20 \mathrm{~h}$ at room temperature. After the time elapsed, the optical densities of the samples were measured using spectrophotometer (Genesys-10 UV-scan, USA) at $530 \mathrm{~nm}$. MDA contents were calculated using a calibration curve established with a standard of 1,1,3,3-tetraethoxypropane solutions (AR-grade, Sigma-Aldrich, Germany). The results were reported as micrograms of MDA per gram of sample.

2.2.4. Hexanal Content. Hexanal content of Kaeb Moo samples was measured using gas chromatography-flame ionization detection (GC-FID) according to Sriwattana et al. [8] and to Akkaravessapong et al. [18] with some modification. Thirty grams of ground sample were extracted by $200 \mathrm{~mL}$ of dichloromethane (RCI Labscan Ltd., Bangkok, Thailand) in an orbital shaker (UM-S6060, UMAC Scientific Co., Ltd., Thailand) for $2 \mathrm{~h}$. After that, the mixture was filtered and evaporated using rotary evaporator (R205, BÜCHI Labortechnik AG, Switzerland) at $40 \pm 1^{\circ} \mathrm{C}$, $200 \mathrm{mbar}$ of pressure for $3 \mathrm{~h}$. Prior to GC-FID analysis, the extract was diluted ten times in hexane (RCI Labscan Ltd., Bangkok, Thailand). Afterwards, $1 \mu \mathrm{l}$ of diluted solution was directly injected to an injection port of GC-FID (GC-2010, Shimadzu, Japan), equipped with a nonpolar column DB-1 
(Agilent Technologies, USA), $30 \mathrm{~m}, 0.249 \mathrm{~mm}$ i.d., $0.25 \mu \mathrm{m}$ film thickness. Helium was used as a carrier gas at a flow rate of $1.0 \mathrm{~mL} / \mathrm{min}$. The temperature program was started at $40^{\circ} \mathrm{C}$, held for $1.5 \mathrm{~min}$, then heated with a rate of $6^{\circ} \mathrm{C} / \mathrm{min}$ to $200^{\circ} \mathrm{C}$, and held at the final temperature for $5 \mathrm{~min}$. With this method, hexanal was eluted $4.90 \mathrm{~min}$ after injection. The hexanal standard curve was generated with a series of concentration (5, 10, 25, 50, 100, and $200 \mathrm{ppm})$ using authentic hexanal (Merck, Germany) in hexane. The hexanal content of each sample (three replications) was calculated compared with the standard curve and expressed in $\mathrm{mg}$ hexanal/kg sample.

2.2.5. Peroxide Value. PV of frying oil of the three Kaeb Moo types was determined according to the AOCS Official Method Cd 8-53 [19]. Five grams of each sample was placed in a $250 \mathrm{~mL}$ stoppered conical flask and $30 \mathrm{~mL}$ of $3: 2$ acetic acid (RCI Labscan Ltd., Bangkok, Thailand)-chloroform (RCI Labscan Ltd., Bangkok, Thailand) solution (v/v) were added into the flask. After it was gently mixed, $0.5 \mathrm{~mL}$ of saturated $\mathrm{KI}$ solution was added to the solution. It was shaken for $1 \mathrm{~min}$, and $30 \mathrm{~mL}$ of distilled water was then immediately added. The obtained solution was titrated with $0.1 \mathrm{~N}$ sodium thiosulfate (RCI Labscan Ltd., Bangkok, Thailand) until the yellow iodine color was almost disappeared. Then, about $2.0 \mathrm{~mL}$ of starch indicator solution was added and the titration was continued until the end point, which the solution became blue in color.

\subsection{Sensory Evaluation}

2.3.1. Descriptive Analysis. A descriptive analysis session was conducted as a procedure described by Grosso and Resurreccion [20]. In this study, 11 panelists ( 9 female and 2 male) who had experience on descriptive sensory analysis were recruited. Panelists were selected according to the criteria defined by Plemmons and Resurreccion [21] with extra requirement that the panelists shall consume Kaeb Moo at least twice per week. The recruited panelists were trained and calibrated for $20 \mathrm{~h}$ ( $2 \mathrm{~h}$ for each training session, for consecutive 10 days) according to the procedures described by Meilgaard et al. [22]. After the training session of characteristic attributes and definitions of Kaeb Moo, the panelists were informed about the definitions of rancidity and crispness [8]. Reference standards for intensity rating (0-150 scale) of each attributes were given to the panelists as listed in Table 1 . The panelists tested and rated each reference. Panelists who did not rate within \pm 10 points of the mean rating score were asked to re-evaluate the sample and adjust their ratings until a consensus was reached.

For Kaeb Moo sample assessment, the panelists evaluated the samples in partitioned booths. The three samples (T1, T2, and T3) including a warm-up sample (freshly prepared Kaeb Moo made in the lab according to $\mathrm{T} 1$ procedure) were assessed every 3 days. The samples were kept in a plastic bag coded with 3 -digit random numbers. The warm-up and reference intensity ratings and definitions were provided for all panelists in each booth in order to calibrate panelist evaluations [20].
TABLE 1: Standard references for intensity rating used for training sensory panelists.

\begin{tabular}{|c|c|c|c|}
\hline Attributes & Reference & Quantity & Intensity $^{1}$ \\
\hline \multirow{4}{*}{$\begin{array}{l}\text { Rancid } \\
\text { (flavor) }^{2}\end{array}$} & $\begin{array}{l}\text { Refined soy bean oil (cook } \\
\text { brand, Thailand) }\end{array}$ & $20.0 \pm 0.1 \mathrm{~g}$ & 0 \\
\hline & $\begin{array}{l}\text { Refined soy bean oil heated at } \\
110^{\circ} \mathrm{C} \text { for } 5 \mathrm{~h}\end{array}$ & $20.0 \pm 0.1 \mathrm{~g}$ & 55 \\
\hline & $\begin{array}{l}\text { Refined soy bean oil heated at } \\
110^{\circ} \mathrm{C} \text { for } 15 \mathrm{~h}\end{array}$ & $20.0 \pm 0.1 \mathrm{~g}$ & 75 \\
\hline & $\begin{array}{l}\text { Refined soy bean oil heated at } \\
110^{\circ} \mathrm{C} \text { for } 24 \mathrm{~h}\end{array}$ & $20.0 \pm 0.1 \mathrm{~g}$ & 100 \\
\hline \multirow{5}{*}{$\begin{array}{l}\text { Crispness } \\
\text { (texture) }^{3}\end{array}$} & $\begin{array}{c}\text { Canned pineapple (Brook } \\
\text { brand, Thailand) }\end{array}$ & $3.20 \mathrm{~cm}^{3}$ & 15 \\
\hline & $\begin{array}{c}\text { Cracker (Nabisco brand, } \\
\text { Thailand) }\end{array}$ & 1 piece & 25 \\
\hline & $\begin{array}{c}\text { New Kaeb Moo (Mae Cham } \\
\text { brand, Thailand) }\end{array}$ & $\begin{array}{l}1 \text { piece } \\
(10 \mathrm{~cm} \\
\text { length) }\end{array}$ & 50 \\
\hline & $\begin{array}{c}\text { Corn chip (Tortillas, Dantitas } \\
\text { brand, Thailand) }\end{array}$ & 1 piece & 70 \\
\hline & $\begin{array}{l}\text { Potato chip (Kettle brand, } \\
\text { USA) }\end{array}$ & 1 piece & 140 \\
\hline
\end{tabular}

${ }^{1}$ Intensity ratings are based on a $150 \mathrm{~mm}$ unstructured line scale with anchor at 12.5 and 137.5. ${ }^{2}$ Adapted from Maisuthisakul et al. [23]. ${ }^{3}$ Adapted from Sriwattana et al. [8] and Chauvin et al. [24].

2.3.2. Consumer Acceptance Test. The consumer acceptance test was performed every week by consumers $(n=50)$ who were nonsmokers and consumed Kaeb Moo at least once a week. The three Kaeb Moo samples, coded with 3-digit random numbers, were served in plastic bags. Overall liking, appearance, odor, crispness, and overall taste based on a 9point hedonic scale $(1=$ dislike extremely, $5=$ neither like nor dislike, and 9=like extremely) were evaluated [25]. In case the consumers detect the rancidity of the samples, they can refuse to evaluate. Furthermore, consumers were asked for their purchase intention.

2.4. Statistical Analysis. Analysis of variance (ANOVA) using SPSS version 16.0 (SPSS Inc., Chicago, IL) was performed to examine significant differences of the evaluated properties among Kaeb Moo samples. Duncan's multiple range test (DMRT) was applied for multiple comparisons. Pearson correlation coefficients were calculated between consumer response and sensory attribute intensity ratings, moisture contents, MDA contents, and texture measurements with hexanal measurements. The significant level of ANOVA, DMRT, and correlation was justified at $p$ value lower than 0.050. Regression analysis was applied to predict consumer responses using sensory attribute intensity ratings, moisture contents, MDA contents, texture measurements, and hexanal measurements. A first- and a second-order polynomial regression models, $Y=b_{\mathrm{o}}+b_{1} X$ and $Y=b_{\mathrm{o}}+b_{1} X+b_{11} X^{2}$, were applied to the obtained data. For the regression models, $Y$ is the value of consumer response; $b_{\mathrm{o}}$ is the intercept when $Y=0$; $b_{1}$ are parameter estimates; $X$ is the sensory attribute intensity ratings, moisture content, MDA content, texture measurements, and hexanal measurements. The criterion of an adjusted $R^{2}$ for regression models was over 0.80 . 


\section{Results and Discussion}

3.1. Moisture Content. The results of moisture content of the three types of Kaeb Moo during storage at $25^{\circ} \mathrm{C}$ are shown in Table 2. It can be seen that the moisture content of all samples increased during the storage time. The percentages of the moisture content, from the first day of production to the last day of storage, ranged from $1.65 \pm 0.04$ to $4.96 \pm 0.17 \%$, $1.62 \pm 0.05$ to $5.02 \pm 0.15 \%$, and $1.93 \pm 0.11$ to $5.04 \pm 0.20 \%$ for $\mathrm{T} 1, \mathrm{~T} 2$, and T3, respectively. T3 samples showed significantly higher moisture content than $\mathrm{T} 1$ and $\mathrm{T} 2$ on the first day. Nevertheless, after 4-day storage, the moisture content of T2 increased and became nonsignificantly different from T3. The moisture contents reported were in the same range of Kaeb moo samples reported in Sriwattana et al. [8]. It was reported for a model snack food, corn ball snack, that the critical moisture content that affected the acceptance is 4\% [26]. According to this parameter, T2 and T3 samples should be unaccepted on after 16 days of storage, while T1 samples should be unaccepted after 25 days of storage.

3.2. Texture Analysis. The texture of Kaeb Moo samples was evaluated and reported as hardness and crispness shown in Table 2. The hardness values of all three samples ranged from 11.34 to $17.00 \mathrm{~kg}_{f}$ throughout the storage period of 31 days. During the storage, the hardness of the T1 and T2 samples did not change; while the hardness of T3 samples slightly increased. The crispness of the three Kaeb Moo types investigated by linear distance value gradually decreased during the storage. The crispness of the three types from the first day of production to the last day of storage was $72.12 \pm 5.65$ to $37.55 \pm 6.47,67.84 \pm 3.95$ to $33.34 \pm 4.60$, and $73.71 \pm 2.93$ to $39.63 \pm 5.47$, for $\mathrm{T} 1, \mathrm{~T} 2$, and $\mathrm{T} 3$, respectively. The higher linear distance indicates more crispness [27]. The decrease of crispness was due to the increasing of moisture contents. It is possible to observe that the higher hardness correlates with the lower crispness. In addition, samples with high moisture content also had high hardness values but low crispness values. This is in agreement with the finding of a corn ball model snack that when its moisture content is above $4 \%$, a decreasing trend in crispness of the snack is detected. In addition, a noticeable decrease of crispness occurs when moisture content is higher 7\% [26].

3.3. Peroxide Value. PV is one quality parameter of oil production and storage. Peroxide is a product of primary oil oxidation and represents the degree of oil oxidation. In Thailand, the standard PV value for Kaeb Moo declared by the Thai Industrial Standards Institute [28] shall not exceed $30 \mathrm{meq}_{2} / \mathrm{kg}$ oil. It was found that PV values of oil after frying each sample types $\mathrm{T} 1, \mathrm{~T} 2$, and $\mathrm{T} 3$ were $4.52 \pm 0.11$, $3.99 \pm 0.01$, and $11.53 \pm 0.25$ meq $\mathrm{O}_{2} / \mathrm{kg}$ oil, respectively. These three values were significantly different $(p<0.05)$ and well in agreement with the standard for oil quality. The low values of PVs may result from the decomposition to secondary products which occur relatively quickly [10]. Even though the peroxide values of the frying oil were under the specification, there is no guarantee that fried Kaeb Moo product is of high quality. Interestingly, it was also reported that PV failed to indicate the quality of palm-olein oil $[12,29]$.

3.4. Malondialdehyde Content. MDA content was found to be similar trend as moisture content, which gradually increased during the storage time. At the beginning of the storage, MDA of $\mathrm{T} 1(0.050 \pm 0.009 \mu \mathrm{g} / \mathrm{g})$ sample was significantly different from T2 $(0.224 \pm 0.017 \mu \mathrm{g} / \mathrm{g})$ and T3 $(0.255 \pm 0.060 \mu \mathrm{g} / \mathrm{g})$ samples, which MDA contents of these two samples were not significantly different. After the first day of storage, MDA contents of each sample increased. At 31-day storage, the MDA contents of Kaeb Moo samples were $0.436 \pm 0.043,1.116 \pm 0.119$, and $1.606 \pm 0.077 \mu \mathrm{g} / \mathrm{g}$, for T1, T2, and T3, respectively. According to our consumer acceptance test using 9-point hedonic scale towards the liking of the products, it was found that the consumers rejected to evaluate Kaeb Moo products because of rancidity flavor when the MDA content was approximately $0.5 \mu \mathrm{g} / \mathrm{g}$. It was reported that the rancidity threshold in meat product is about 1-2 mg MDA/kg. Furthermore, consumers are unlikely able to detect off-flavor at values below $0.5 \mathrm{mg} \mathrm{MDA} /$ $\mathrm{kg}[30,31]$. In a study on chicken nuggets, it was found that panelists could detect a slightly off-flavor when the product had an MDA concentration of $0.5 \mu \mathrm{g} / \mathrm{g}$ [32]. Wanstedt et al. [33] reported that MDA values ranging from 0.6 to 1 are associated with organoleptically detectable rancidity in cooked pork. On the contrary, Campo et al. [34] considered a limiting threshold of MDA in beef steak equal to $2 \mu \mathrm{g} / \mathrm{g}$. Moreover, according to Hughes et al. [35], it was reported that a concentration of $2.60-3.11 \mu \mathrm{g} / \mathrm{g}$ of MDA was still acceptable to consumers in aged beef striploins. In case of $\mathrm{Kaeb} \mathrm{Moo}$, it seems that even a low concentration of MDA is able to lead to rancidity detection by consumers. This is probably due to the fact that there are no spices added which may cover the off-flavor. Therefore, there is no aroma masking rancid flavor in the overall odor of Kaeb Moo.

3.5. Hexanal Contents. Hexanal, an aldehyde responsible for oxidative off-flavor of fried or oil-containing food products, was monitored during the storing period. It has been identified as a product of linoleic acid oxidation, and its contents increase as function of storage time [20]. The factors influencing the amount of hexanal content are light, temperature, and oxygen [36]. Figure 1 shows the hexanal contents of each sample. It can be seen that during the storage time, hexanal contents of the three samples were significantly different, except the first day, during which $\mathrm{T} 1$ and $\mathrm{T} 2$ were not different, but $\mathrm{T} 3$. For $\mathrm{T} 1$ sample, the hexanal content was $1.725 \pm 0.034 \mathrm{mg} / \mathrm{kg}$ for the first day, and then it slightly increased during the storage to $3.888 \pm 0.051 \mathrm{mg} / \mathrm{kg}$ on the last day of storage. The T2 sample hexanal content was $1.762 \pm 0.010 \mathrm{mg} / \mathrm{kg}$ for the first day, and then it increased to $9.544 \pm 0.189 \mathrm{mg} / \mathrm{kg}$ on the last day of storage. The hexanal contents of T3 sample were drastically increased from $1.990 \pm 0.032 \mathrm{mg} / \mathrm{kg}$ to $19.140 \pm 0.212 \mathrm{mg} / \mathrm{kg}$. It is interesting to note that the PV of the frying oil of T1 and T2 samples were very close, and the MDA content of T2 and T3 samples was the same. However, hexanal contents of each sample developed differently. 


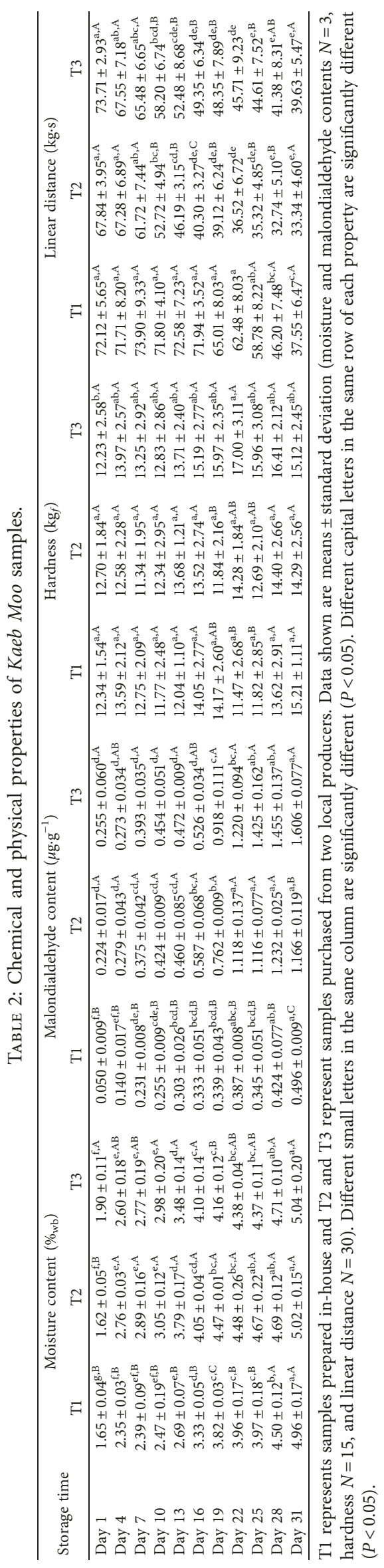




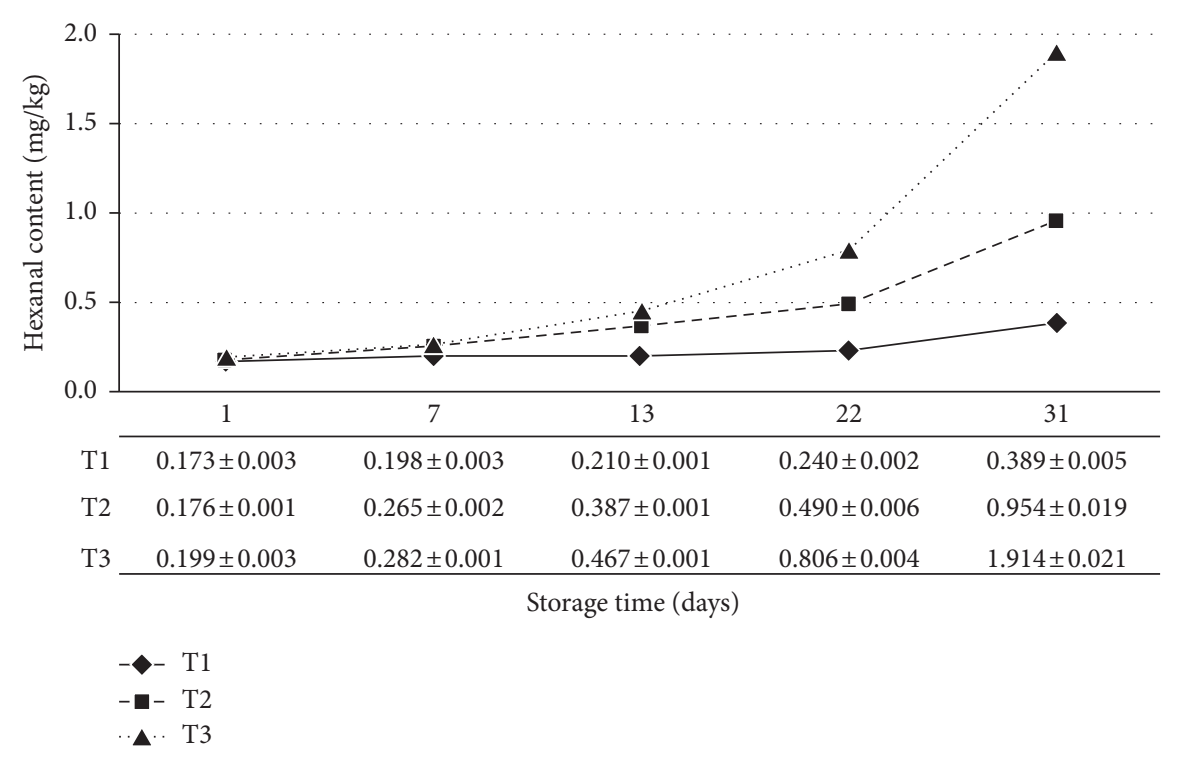

Figure 1: Hexanal contents of Kaeb Moo samples during storage.

TABle 3: Means of sensory attribute ratings of Kaeb Moo samples using $150 \mathrm{~mm}$ scale.

\begin{tabular}{|c|c|c|c|c|c|c|}
\hline \multirow{2}{*}{ Storage time (days) } & \multicolumn{3}{|c|}{ Rancidity } & \multicolumn{3}{|c|}{ Crispness } \\
\hline & $\mathrm{T} 1$ & $\mathrm{~T} 2$ & T3 & $\mathrm{T} 1$ & $\mathrm{~T} 2$ & $\mathrm{~T} 3$ \\
\hline 1 & $5.0 \pm 1.4^{\mathrm{i}, \mathrm{B}}$ & $10.3 \pm 1.3^{\mathrm{j}, \mathrm{A}}$ & $9.0 \pm 2.3^{\mathrm{j}, \mathrm{A}}$ & $51.5 \pm 1.9^{\mathrm{a}, \mathrm{A}}$ & $51.8 \pm 2.5^{\mathrm{a}, \mathrm{A}}$ & $53.0 \pm 3.6^{\mathrm{a}, \mathrm{A}}$ \\
\hline 4 & $10.1 \pm 1.4^{\mathrm{h}, \mathrm{B}}$ & $19.9 \pm 3.4^{\mathrm{i}, \mathrm{A}}$ & $22.3 \pm 2.6^{\mathrm{i}, \mathrm{A}}$ & $51.4 \pm 1.7^{\mathrm{a}, \mathrm{A}}$ & $51.5 \pm 2.3^{\mathrm{a}, \mathrm{A}}$ & $50.9 \pm 2.1^{\mathrm{a}, \mathrm{A}}$ \\
\hline 7 & $11.0 \pm 1.6^{\mathrm{h}, \mathrm{C}}$ & $29.5 \pm 1.4^{\mathrm{h}, \mathrm{B}}$ & $32.1 \pm 2.4^{\mathrm{h}, \mathrm{A}}$ & $50.8 \pm 1.6^{\mathrm{a}, \mathrm{A}}$ & $49.7 \pm 1.7^{\mathrm{a}, \mathrm{A}}$ & $49.8 \pm 1.4^{\mathrm{a}, \mathrm{A}}$ \\
\hline 10 & $14.9 \pm 2.0^{\mathrm{g}, \mathrm{C}}$ & $33.8 \pm 1.7^{\mathrm{g}, \mathrm{B}}$ & $38.3 \pm 2.6^{\mathrm{g}, \mathrm{A}}$ & $50.2 \pm 0.9^{\mathrm{a}, \mathrm{A}}$ & $46.5 \pm 2.3^{\mathrm{b}, \mathrm{B}}$ & $45.7 \pm 1.9^{\mathrm{b}, \mathrm{B}}$ \\
\hline 13 & $21.4 \pm 1.8^{\mathrm{f}, \mathrm{A}}$ & $41.8 \pm 2.3^{\mathrm{f}, \mathrm{B}}$ & $50.3 \pm 2.8^{\mathrm{f}, \mathrm{C}}$ & $45.3 \pm 1.2^{\mathrm{b}, \mathrm{A}}$ & $40.2 \pm 2.5^{\mathrm{c}, \mathrm{B}}$ & $40.6 \pm 1.5^{\mathrm{c}, \mathrm{B}}$ \\
\hline 16 & $25.9 \pm 1.4^{\mathrm{e}, \mathrm{C}}$ & $51.6 \pm 2.2^{\mathrm{e}, \mathrm{B}}$ & $60.4 \pm 1.6^{\mathrm{e}, \mathrm{A}}$ & $43.5 \pm 3.0^{\mathrm{bc}, \mathrm{A}}$ & $40.3 \pm 1.7^{\mathrm{c}, \mathrm{B}}$ & $39.8 \pm 1.2^{\mathrm{c}, \mathrm{B}}$ \\
\hline 19 & $30.7 \pm 1.4^{\mathrm{d}, \mathrm{C}}$ & $61.5 \pm 3.6^{\mathrm{d}, \mathrm{B}}$ & $71.2 \pm 2.4^{\mathrm{d}, \mathrm{A}}$ & $41.1 \pm 1.1^{\mathrm{cd}, \mathrm{A}}$ & $40.5 \pm 2.8^{\mathrm{c}, \mathrm{A}}$ & $39.2 \pm 1.7^{\mathrm{c}, \mathrm{A}}$ \\
\hline 22 & $41.8 \pm 1.9^{\mathrm{c}, \mathrm{C}}$ & $70.2 \pm 3.3^{\mathrm{c}, \mathrm{B}}$ & $79.3 \pm 2.9^{\mathrm{c}, \mathrm{A}}$ & $40.8 \pm 1.9^{\mathrm{d}, \mathrm{A}}$ & $40.0 \pm 3.6^{\mathrm{c}, \mathrm{A}}$ & $39.7 \pm 1.4^{\mathrm{c}, \mathrm{A}}$ \\
\hline 25 & $41.7 \pm 1.8^{\mathrm{c}, \mathrm{D}}$ & $81.0 \pm 3.3^{\mathrm{b}, \mathrm{B}}$ & $88.1 \pm 2.0^{\mathrm{b}, \mathrm{C}}$ & $39.6 \pm 1.3^{\mathrm{d}, \mathrm{A}}$ & $29.5 \pm 2.3^{\mathrm{d}, \mathrm{B}}$ & $26.6 \pm 3.1^{\mathrm{d}, \mathrm{C}}$ \\
\hline 28 & $46.0 \pm 1.8^{\mathrm{b}, \mathrm{C}}$ & $89.3 \pm 3.2^{\mathrm{a}, \mathrm{B}}$ & $92.3 \pm 2.5^{\mathrm{a}, \mathrm{A}}$ & $35.2 \pm 1.8^{\mathrm{e}, \mathrm{A}}$ & $23.8 \pm 1.6^{\mathrm{e}, \mathrm{B}}$ & $24.7 \pm 3.7^{\mathrm{de}, \mathrm{B}}$ \\
\hline 31 & $53.6 \pm 3.3^{\mathrm{a}, \mathrm{B}}$ & $92.1 \pm 2.6^{\mathrm{a}, \mathrm{A}}$ & $93.0 \pm 2.1^{\mathrm{a}, \mathrm{A}}$ & $34.3 \pm 1.7^{\mathrm{e}, \mathrm{A}}$ & $22.6 \pm 2.2^{\mathrm{e}, \mathrm{B}}$ & $23.2 \pm 2.7^{\mathrm{e}, \mathrm{B}}$ \\
\hline
\end{tabular}

$\mathrm{T} 1$ represents samples prepared in-house and T2 and T3 represent samples purchased from two local producers. Data shown are means \pm standard deviations $(N=11)$. Different small letters in the same column are significantly different $(P<0.05)$. Different capital letters in the same row of each attributes are significantly different $(P<0.05)$.

\subsection{Sensory Evaluation}

3.6.1. Descriptive Analysis. The change of Kaeb Moo qualities, rancid flavor and crispness, was monitored by descriptive analysis. The mean values of the attribute ratings evaluated by 11 trained panelists are presented in Table 3. At the first day of production, the rancid intensity of T1 was significantly different from T2 and T3 $(p<0.05)$. It is interesting to note that even though the hexanal contents of $\mathrm{T} 1$ and $\mathrm{T} 2$ were not significantly different, the panelists detected different intensities of rancid flavor of the two samples. In this case, there might be other compounds contributing to the rancid flavor of Kaeb Moo. It was reported that aldehydes, e.g., heptanal, (E,E)-2,4-decadienal, and $(E, Z)-2,6$ nonadienal, are very important products from lipid oxidation and are the main compounds contributing to rancid flavor development $[8,10]$. During the storage, the rancid flavor of T1 slowly increased, while the rancid intensity of T2 and T3 drastically increased. At the end of the storage time, the rancid intensity of T1 was about half of T2 and T3, which has significant difference $(p<0.05)$.

The crispness intensity of T1 sample remained unchanged during 10 days of storage, whereas the crispness of T2 and T3 remained unchanged for 7 days. The crispness of all the samples gradually decreased. The crispness intensity of T1 was about $34 \mathrm{~mm}$, while the crispness of T2 and T3 was about $23 \mathrm{~mm}$ which was close to the crispness of cracker $(25 \mathrm{~mm})$ on the last day of storage.

3.6.2. Consumer Acceptance Test. In addition to the descriptive analysis, the 9-point hedonic scale test was acquired for the evaluation of consumer acceptance towards the three pork scratching samples. Overall liking, appearance, odor, texture, crispness, and taste of the samples were evaluated. The results are shown in Table 4 . It can be seen that, at the first day of production, the consumers evaluated all the samples from like slightly to like very much (6-8 points). 
TABLe 4: Sensory acceptance test of Kaeb Moo attributes using a 9-point hedonic scale and \% purchase intent.

\begin{tabular}{|c|c|c|c|c|c|c|c|c|}
\hline \multirow{2}{*}{ Storage times (weeks) } & \multirow{2}{*}{ Sample } & \multicolumn{6}{|c|}{ Attributes } & \multirow{2}{*}{$\%$ purchase intent } \\
\hline & & Overall liking & Appearance & Odor & Texture & Crispness & Overall taste & \\
\hline \multirow{3}{*}{0} & $\mathrm{~T} 1$ & $7.6 \pm 0.9^{\mathrm{a}, \mathrm{x}}$ & $7.2 \pm 1.0^{\mathrm{a}, \mathrm{x}}$ & $7.5 \pm 0.9^{\mathrm{a}, \mathrm{x}}$ & $7.7 \pm 0.8^{\mathrm{a}, \mathrm{x}}$ & $7.9 \pm 0.7^{\mathrm{a}, \mathrm{x}}$ & $7.7 \pm 0.7^{\mathrm{a}, \mathrm{x}}$ & 100.00 \\
\hline & $\mathrm{T} 2$ & $6.9 \pm 1.0^{\mathrm{a}, \mathrm{y}}$ & $7.4 \pm 0.8^{\mathrm{a}, \mathrm{x}}$ & $6.9 \pm 1.0^{\mathrm{a}, \mathrm{y}}$ & $7.0 \pm 1.0^{\mathrm{a}, \mathrm{y}}$ & $7.3 \pm 0.9^{\mathrm{a}, \mathrm{y}}$ & $7.0 \pm 0.9^{\mathrm{a}, \mathrm{y}}$ & 93.55 \\
\hline & $\mathrm{T} 3$ & $6.6 \pm 0.8^{\mathrm{a}, \mathrm{y}}$ & $6.9 \pm 0.8^{\mathrm{a}, \mathrm{x}}$ & $6.6 \pm 1.0^{\mathrm{a}, \mathrm{y}}$ & $6.8 \pm 1.0^{\mathrm{a}, \mathrm{y}}$ & $7.1 \pm 0.9^{\mathrm{a}, \mathrm{y}}$ & $6.5 \pm 1.1^{\mathrm{a}, \mathrm{y}}$ & 83.87 \\
\hline \multirow{3}{*}{1} & $\mathrm{~T} 1$ & $7.1 \pm 0.8^{\mathrm{ab}, \mathrm{x}}$ & $6.9 \pm 0.7^{\mathrm{a}, \mathrm{x}}$ & $6.8 \pm 0.8^{\mathrm{b}, \mathrm{x}}$ & $6.8 \pm 0.8^{\mathrm{b}, \mathrm{x}}$ & $6.9 \pm 0.7^{\mathrm{b}, \mathrm{x}}$ & $6.9 \pm 0.7^{\mathrm{b}, \mathrm{x}}$ & 96.88 \\
\hline & $\mathrm{T} 2$ & $6.1 \pm 1.0^{\mathrm{b}, \mathrm{y}}$ & $6.8 \pm 0.8^{\mathrm{ab}, \mathrm{xy}}$ & $6.4 \pm 0.8^{\mathrm{a}, \mathrm{x}}$ & $6.4 \pm 0.9^{\mathrm{b}, \mathrm{xy}}$ & $6.2 \pm 0.8^{\mathrm{b}, \mathrm{y}}$ & $6.3 \pm 0.8^{b, y}$ & 75.00 \\
\hline & T3 & $5.9 \pm 0.8^{\mathrm{b}, \mathrm{y}}$ & $6.4 \pm 1.0^{\mathrm{ab}, \mathrm{y}}$ & $5.7 \pm 0.9^{\mathrm{a}, \mathrm{y}}$ & $5.9 \pm 1.0^{\mathrm{b}, \mathrm{y}}$ & $6.0 \pm 0.9^{\mathrm{b}, \mathrm{y}}$ & $5.8 \pm 1.0^{\mathrm{a}, \mathrm{y}}$ & 62.50 \\
\hline \multirow{3}{*}{2} & $\mathrm{~T} 1$ & $6.6 \pm 0.9^{\mathrm{b}, \mathrm{x}}$ & $7.0 \pm 0.9^{\mathrm{a}, \mathrm{x}}$ & $6.2 \pm 0.9^{\mathrm{bc}, \mathrm{x}}$ & $6.3 \pm 1.0^{\mathrm{b}, \mathrm{x}}$ & $6.4 \pm 1.0^{\mathrm{b}, \mathrm{x}}$ & $6.6 \pm 1.0^{\mathrm{b}, \mathrm{x}}$ & 68.57 \\
\hline & $\mathrm{T} 2$ & $4.5 \pm 0.8^{c, y}$ & $6.8 \pm 0.9^{\mathrm{b}, \mathrm{x}}$ & $5.5 \pm 1.0^{\mathrm{b}, \mathrm{y}}$ & $4.8 \pm 1.0^{\mathrm{c}, \mathrm{y}}$ & $4.2 \pm 1.0^{\mathrm{c}, \mathrm{y}}$ & $4.9 \pm 0.8^{c, y}$ & 42.86 \\
\hline & T3 & $3.9 \pm 1.0^{c, z}$ & $6.6 \pm 0.8^{\mathrm{b}, \mathrm{x}}$ & $4.9 \pm 1.0^{c, z}$ & $4.5 \pm 1.0^{c, y}$ & $4.3 \pm 1.0^{c, y}$ & $4.5 \pm 1.1^{\mathrm{b}, \mathrm{y}}$ & 34.29 \\
\hline \multirow{3}{*}{3} & $\mathrm{~T} 1$ & $5.7 \pm 0.9^{\mathrm{c}}$ & $6.9 \pm 0.9^{\mathrm{a}}$ & $5.8 \pm 1.0^{c}$ & $5.6 \pm 1.0^{c}$ & $5.7 \pm 0.9^{c}$ & $6.3 \pm 0.9^{b}$ & 60.00 \\
\hline & $\mathrm{T} 2$ & - & - & - & - & - & - & - \\
\hline & $\mathrm{T} 3$ & - & - & - & - & - & - & - \\
\hline \multirow{3}{*}{4} & $\mathrm{~T} 1$ & $4.2 \pm 0.9^{\mathrm{d}}$ & $6.7 \pm 1.0^{\mathrm{a}}$ & $5.0 \pm 1.0^{c}$ & $4.6 \pm 1.1^{\mathrm{d}}$ & $4.1 \pm 1.4^{\mathrm{d}}$ & $5.0 \pm 1.4^{\mathrm{c}}$ & 46.67 \\
\hline & $\mathrm{T} 2$ & - & - & - & - & - & - & - \\
\hline & T3 & - & - & - & - & - & - & - \\
\hline
\end{tabular}

Data shown are means \pm standard deviation $(N=50)$. a, b, $\mathrm{c}$, and $\mathrm{d}$ in the same column show significantly different $(P<0.05)$ values of the same sample in different weeks. $\mathrm{x}, \mathrm{y}$, and $\mathrm{z}$ in the same column show significantly different $(P<0.05)$ values of different same samples in the same weeks. -: evaluation was refused by consumers due to product rancidity.

Especially T1, in-house-production sample, all attributes were in a range of like moderately to like very much (7-8 points). After one week of storage, the hedonic scores of all attributes of $\mathrm{T} 1, \mathrm{~T} 2$, and $\mathrm{T} 3$ were decreased to like slightly to like moderately (6-7 points), except the overall liking, odor, texture, and overall taste of $\mathrm{T} 3$ sample were in a range of neither like nor dislike to moderately like (5-6 points). After two weeks of storage, the scores of overall liking and overall taste of T2 and T3 samples were lower than 5 and the purchase intent was lower than $50 \%$, which can be considered as a level to decide that a food is unacceptable for the consumer [20]. On the contrary, the hedonic scores of all attributes of $\mathrm{T} 1$ were like slightly to like moderately (6-7 points). After four weeks of storage, the overall liking score of T1 sample was 4.23. Interestingly, the appearance scores of every sample remained in a range of like slightly to like moderately (6-7 points) during the testing period. This was because the appearance of Keab Moo was not affected by storage, as well as other kinds of fried products. Therefore, the quality of fried products cannot be judged by only the appearance. In contrast, odor, crispness, and overall taste play important roles in consumer acceptance and related to overall acceptability of fried products. This result was in an agreement with the study of Sriwattana et al. [8]. Purchase intentions of consumers were in parallel conducted and the results are shown in Table 4. The percentages of purchasing of samples gradually decreased. For T1 sample, the \% purchase intention was lower than 50 in week 4 of storage, while T2 and T3 samples were in 2-week storage.

3.7. Regression Analysis. Table 5 shows the results of regression analysis (regression equations and adjusted $R^{2}$ ), presenting the equations with $R^{2}$ over 0.8 . The physical and chemical properties and descriptive analysis were independent variables $(x)$, while the overall acceptance of
TABLE 5: Regression equations derived from independent variables $x$ in physical, chemical, and descriptive analysis to predict overall acceptance $y$ of Kaeb Moo.

$$
\text { Overall acceptance }(y)
$$

\begin{tabular}{|c|c|c|c|}
\hline Variables $(x)$ & $\begin{array}{c}\text { Regression } \\
\text { equations }\end{array}$ & $\begin{array}{c}\text { Adjusted } \\
R^{2}\end{array}$ & $\begin{array}{c}\text { Significance } \\
\text { level }\end{array}$ \\
\hline \multicolumn{4}{|l|}{ T1 sample } \\
\hline Moisture content & $\begin{array}{c}y=8.20-0.19 x+ \\
0.12 x^{2}\end{array}$ & 0.978 & $p<0.01$ \\
\hline MDA content & $\begin{array}{c}y=7.52+2.54 x- \\
18.62 x^{2}\end{array}$ & 0.999 & $p<0.01$ \\
\hline Hexanal content & $\begin{array}{c}y=16.02-62.09 x+ \\
81.48 x^{2}\end{array}$ & 0.984 & $p<0.01$ \\
\hline $\begin{array}{l}\text { Linear distance } \\
\text { Descriptive analysis }\end{array}$ & $y=1.00+0.08 x$ & 0.832 & $p<0.05$ \\
\hline Rancidity & $y=7.93-0.06 x$ & 0.943 & $p<0.01$ \\
\hline Crispness & $\begin{array}{c}y=-9.82+ \\
0.56 x-0.01 x^{2}\end{array}$ & 0.974 & $p<0.01$ \\
\hline \multicolumn{4}{|l|}{ T2 sample } \\
\hline Moisture content & $\begin{array}{c}y=5.83+1.35 x- \\
0.43 x^{2}\end{array}$ & 0.981 & $p<0.05$ \\
\hline MDA content & $y=8.60-7.16 x$ & 0.967 & $p<0.10$ \\
\hline Hexanal content & $\begin{array}{c}y=9.70-16.61 x+ \\
8.40 x^{2}\end{array}$ & 0.992 & $p<0.05$ \\
\hline $\begin{array}{l}\text { Linear distance } \\
\text { Descriptive analysis }\end{array}$ & $y=-0.57+0.11 x$ & 0.994 & $p<0.05$ \\
\hline Rancidity & $y=7.67-0.06 x$ & 0.999 & $p<0.05$ \\
\hline Crispness & $y=-2.87+0.18 x$ & 0.947 & $p<0.05$ \\
\hline \multicolumn{4}{|l|}{ T3 sample } \\
\hline Moisture content & $y=10.08-1.73 x$ & 0.917 & $p<0.05$ \\
\hline MDA content & $y=10.00-12.63 x$ & 0.922 & $p<0.10$ \\
\hline Hexanal content & $\begin{array}{c}y=8.91- \\
12.05 x+4.14 x^{2}\end{array}$ & 0.986 & $p<0.05$ \\
\hline $\begin{array}{l}\text { Linear distance } \\
\text { Descriptive analysis }\end{array}$ & $y=-2.81+0.13 x$ & 0.960 & $p<0.10$ \\
\hline Rancidity & $y=7.52-0.07 x$ & 0.941 & $p<0.05$ \\
\hline Crispness & $y=-4.93+0.22 x$ & 0.999 & $p<0.01$ \\
\hline
\end{tabular}


consumers was a dependent variable $(y)$. The independent variables included moisture content, MDA content, hexanal content, linear distance, rancid rating, and crispness rating. The end of the product shelf life, considered from an unacceptable level for consumers [20], and the properties of Kaeb Moo samples from predicting equations were as follows: $3.67-6.01 \%$ moisture contents, $0.396-0.503 \mu \mathrm{g} / \mathrm{g}$ MDA contents, $\quad 0.342-0.481 \mathrm{mg} / \mathrm{kg}$ hexanal contents, $50.01-$ $60.08 \mathrm{~kg}$.s linear distances (crispness), $36.01-48.83 \mathrm{~mm}$ rancid rating, and $43.72-45.38 \mathrm{~mm}$ crispness rating.

\section{Conclusions}

Our study showed for the first time that chemical and physical properties measured in Kaeb Moo can be used for prediction of consumers' acceptance. For the products with low-quality process control, all the properties can be used to predict the consumers' acceptance, while the products with high-quality process control moisture and hexanal contents and descriptive analysis shall be applied. However, this research pointed out that monitoring of hexanal contents may be used a key indicator for evaluation of Kaeb Moo quality and its shelf life.

\section{Data Availability}

Research data used to support the findings of this study are included within the article.

\section{Conflicts of Interest}

The authors declare that there are no conflicts of interest.

\section{Acknowledgments}

The authors would like to thank the National Research Council of Thailand (NRCT) for partial research funding with a project number PARD/2558-A6.11.

\section{References}

[1] E. Choe and D. B. Min, "Chemistry of deep-fat frying oils," Journal of Food Science, vol. 72, no. 5, pp. R77-R86, 2007.

[2] V. Oreopoulou, M. Krokida, and D. Marinos-Kouris, "Chapter 59: frying of foods," in Handbook of Industrial Drying, pp. 1189-1208, Taylor \& Francis Group LLC, Boca Raton, FL, USA, 2015.

[3] Q. Qi, A. Y. Chu, J. H. Kang et al., "Fried food consumption, genetic risk, and body mass index: gene-diet interaction analysis in three US cohort studies," BMJ, vol. 348, pp. 1-12, 2014.

[4] T. Gadiraju, Y. Patel, J. Gaziano, and L. Djoussé, "Fried food consumption and cardiovascular health: a review of current evidence," Nutrients, vol. 7, pp. 8424-8430, 2015.

[5] P. Hu, Y. Li, and H. Campos, "Fried food intake and risk of nonfatal acute myocardial infarction in the Costa Rica Heart Study," PLoS One, vol. 13, no. 2, Article ID e0192960, 2018.

[6] N. Chommanar, "Consumers' purchasing behavior towards crispy pork skin in Mueang district, Chiang Mai Province," Master Thesis in Business Administration Program, Chiang Mai University, Chiang Mai, Thailand, 2007, in Thai.
[7] M. Maugkul, S. Kunakornbadin, K. Maugkun et al., "The development and technological transfering of pork cracker production in Chiang Rai province," Area Based Development Research Journal, vol. 3, pp. 70-82, 2011.

[8] S. Sriwattana, N. Utama-ang, P. Thakeow et al., "Physical, chemical and sensory characterization of the Thai-crispy pork rind 'Kaeb Moo'," Chiang Mai University Journal of Natural of Sciences, vol. 11, no. 1, pp. 181-191, 2011.

[9] W. Chitsamphandhvej, W. Phakdee, and W. Thanasan, "A headspace solid phase microextraction method for using to monitor hexanal and heptanal content in food samples," Kasetsart Journal (Natural Science), vol. 42, pp. 206-212, 2008.

[10] C. F. Ross and D. M. Smith, "Use of volatiles as indicators of lipid oxidation in muscle foods," Comprehensive Reviews in Food Science and Food Safety, vol. 5, no. 1, pp. 18-25, 2006.

[11] A. Meynier, C. Genot, and G. Gandemer, "Volatile compounds of oxidized pork phospholipids," Journal of the American Oil Chemists' Society, vol. 75, no. 1, pp. 1-7, 1998.

[12] G. H. van der Merwe, L. M. du Plessis, and J. R. Taylor, "Changes in chemical quality indices during long-term storage of palm-olein oil under heated storage and transport-type conditions," Journal of the Science of Food and Agriculture, vol. 84, no. 1, pp. 52-58, 2003.

[13] H. Esterbauer, "Cytotoxicity and genotoxicity of lipidoxidation products," The American Journal of Clinical Nutrition, vol. 57, no. 5, pp. 779S-786S, 1993.

[14] C. M. Seppanen and A. Saari Csallany, "Formation of 4hydroxynonenal, a toxic aldehyde, in soybean oil at frying temperature," Journal of the American Oil Chemists' Society, vol. 79, no. 10, pp. 1033-1038, 2002.

[15] G. Barrera, "Oxidative stress and lipid peroxidation products in cancer progression and therapy," ISRN Oncology, vol. 2012, Article ID 137289, 21 pages, 2012.

[16] Association of Official Agricultural Chemistry, Official Methods of Analysis International, AOAC, Gaithersburg, MD, USA, 17th edition, 2000.

[17] D. D. Miller, "Chapter 10: lipid oxidation," in Food Chemistry: A Laboratory Manual, pp. 57-67, John Wiley \& Sons, Inc., New York, NY, USA, 1998.

[18] P. Akkaravessapong, A. Wasusun, and S. Wongpornchai, "Comparisons of acylated steryl glucosides in pigment brown and pre-germinated brown rice," in The 30th Rice and Temperate Cereal Crops Annual Conference, Maruay Garden Hotel, Bangkok, Thailand, 2013.

[19] American Oil Chemists' Society, Official Methods and Recommended Practices of the AOCS, American Oil Chemists' Society, Champaign, IL, USA, 5th edition, 1998.

[20] N. R. Grosso and A. V. A. Resurreccion, "Predicting consumer acceptance ratings of cracker-coated and roasted peanuts from descriptive analysis and hexanal measurements," Journal of Food Science, vol. 67, no. 4, pp. 1530-1537, 2002.

[21] L. E. Plemmons and A. V. A. Resurreccion, "A warm-up sample improves reliability of responses in descriptive analysis," Journal of Sensory Studies, vol. 13, no. 4, pp. 359-376, 1998.

[22] M. Meilgaard, G. V. Civille, and B. T. Carr, "Chapter 8: selection and training of panel members," in Sensory Evaluation Techniques, pp. 135-183, Taylor \& Francis Group LLC, Boca Raton, FL, USA, 1991.

[23] P. Maisuthisakul, M. H. Gordon, R. Pongsawatmanit, and M. Suttajit, "Enhancing the oxidative stability of rice cracker by addition of the ethanolic extract of phytochemicals from Cratoxylum formosum Dryer," Asia Pacific Journal of Clinical Nutrition, vol. 16, no. 1, pp. 37-42, 2007. 
[24] M. A. Chauvin, F. Younce, C. Ross, and B. Swanson, "Standard scales for crispness, crackliness and crunchiness in dry and wet foods: relationship with acoustical determinations," Journal of Texture Studies, vol. 39, pp. 345-368, 2008.

[25] D. R. Peryam and F. J. Pilgrim, "Hedonic scale method of measuring food preferences," Food Technology, vol. 11, pp. 9-14, 1957.

[26] P. Mazumder, B. S. Roopa, and S. Bhattacharya, "Textural attributes of a model snack food at different moisture contents," Journal of Food Engineering, vol. 79, no. 2, pp. 511-516, 2007.

[27] C. A. Nalesnik, C. I. Onwulata, M. H. Tunick, J. G. Phillips, and P. M. Tomasula, "The effects of drying on the properties of extruded whey protein concentrates and isolates," Journal of Food Engineering, vol. 80, pp. 688-694, 2007.

[28] Thai Industrial Standards Institute, Thai Community Product Standard for Kaeb Moo (Crispy Pork Rind) 101/2553, Thai Industrial Standards Institute, Ministry of Industry, Bangkok, Thailand, 2010, in Thai.

[29] L. Meyer, S. Orellana, C. Saravia, C. Galdames, and M. C. Perez-Camino, "Quality of lipid fractions in deep-fried foods from street," Journal of Food Quality, vol. 2018, Article ID 7878439, 8 pages, 2018.

[30] I. T. Kadim and O. Mahgoub, "Chapter 7: postharvest handling of red meat," in Handbook of Food Preservation, pp. 173-202, Taylor \& Francis Group LLC, Boca Raton, FL, USA, 2007.

[31] S. Marcinčák, "Chapter 21: lipid oxidation of fermented meat product," in Fermented Meat Products: Health Aspects, Taylor \& Francis Group LLC, Boca Raton, FL, USA, 2016.

[32] S.-M. Lai, J. I. Gray, A. M. Booren, R. L. Crackel, and J. L. Gill, "Assessment of off-flavor development in restructured chicken nuggets using hexanal and TBARS measurements and sensory evaluation," Journal of the Science of Food and Agriculture, vol. 67, no. 4, pp. 441-452, 1995.

[33] K. G. Wanstedt, S. C. Seideman, L. S. Donnelly, and N. M. Quenzer, "Sensory attributes of precooked, calcium alginate-coated pork patties," Journal of Food Protection, vol. 44, no. 10, pp. 732-735, 1981.

[34] M. M. Campo, G. R. Nute, S. I. Hughes, M. Enser, J. D. Wood, and R. I. Richardson, "Flavour perception of oxidation in beef," Meat Science, vol. 72, no. 2, pp. 303-311, 2006.

[35] J. M. Hughes, N. G. McPhail, G. Kearney, F. Clarke, and R. D. Warner, "Beef longissimus eating quality increases up to 20 weeks of storage and is unrelated to meat colour at carcass grading," Animal Production Science, vol. 55, no. 2, pp. 174$179,2015$.

[36] P. N. Jensen, B. Danielsen, G. Bertelsen, L. H. Skibsted, and M. L. Andersen, "Storage stabilities of pork scratchings, peanuts, oatmeal and muesli: comparison of ESR spectroscopy, headspace-GC and sensory evaluation for detection of oxidation in dry foods," Food Chemistry, vol. 91, no. 1, pp. 25-38, 2005. 


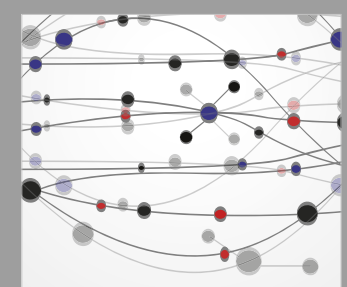

The Scientific World Journal
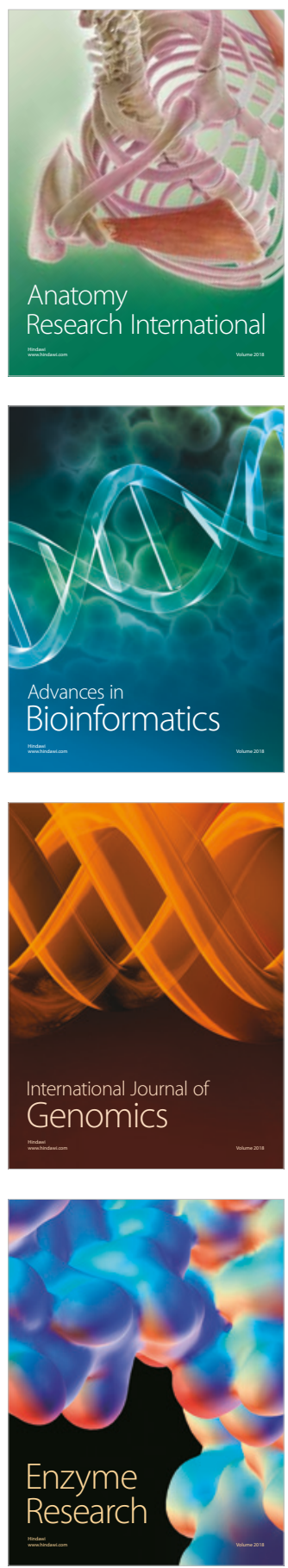
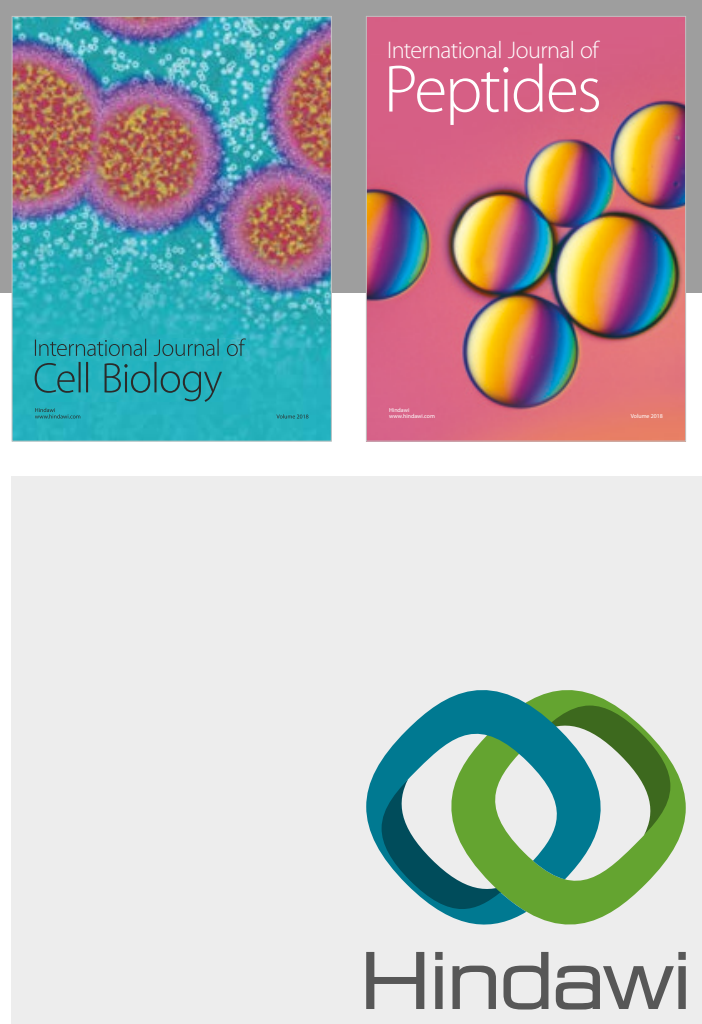

Submit your manuscripts at

www.hindawi.com
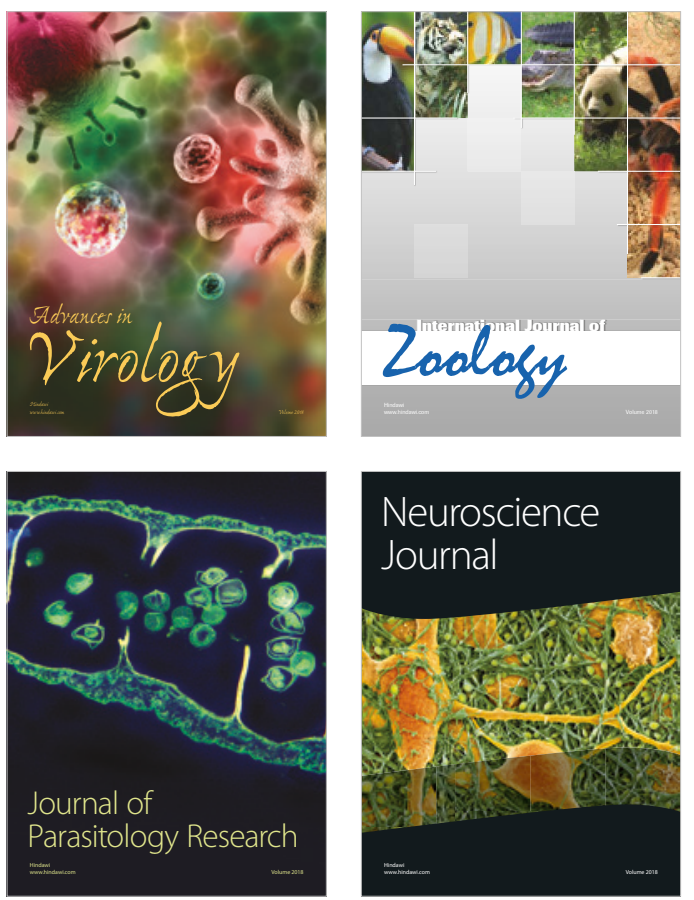
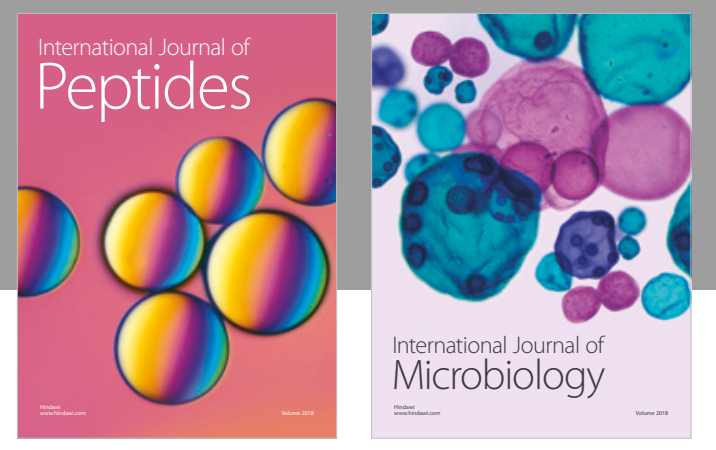

nternational Journal of Microbiology
Journal of
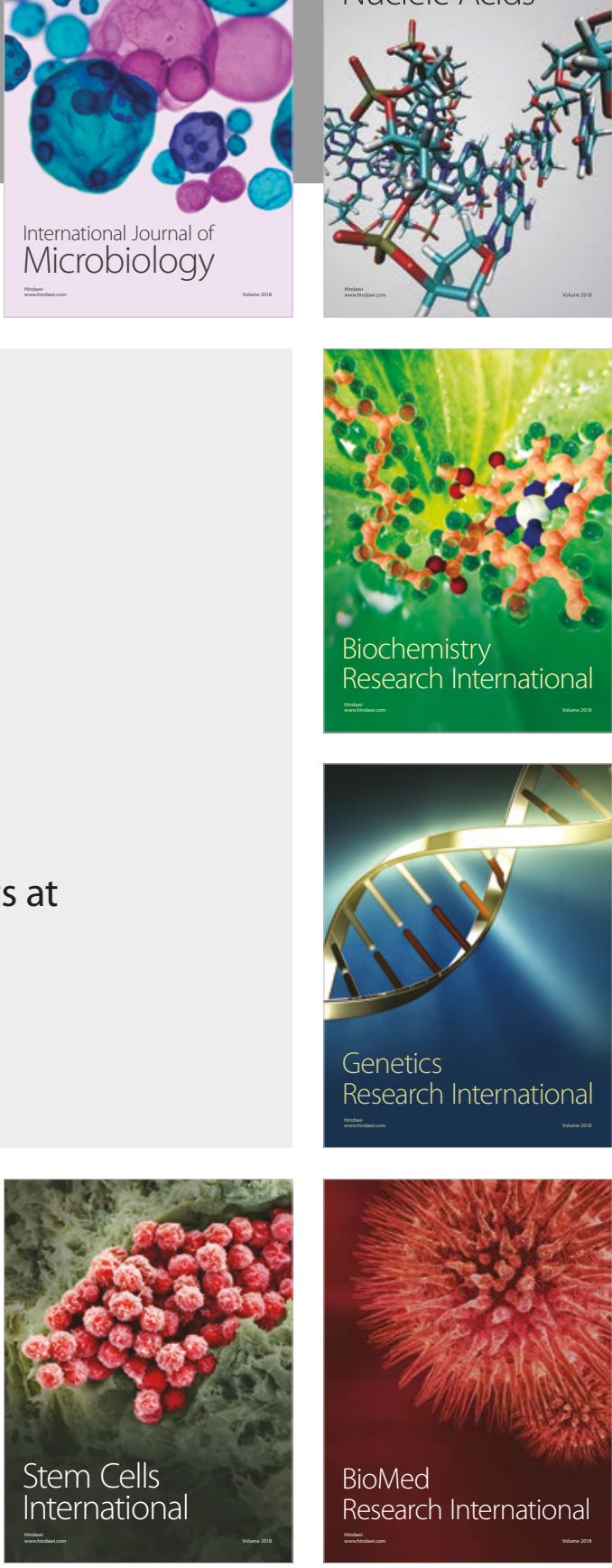
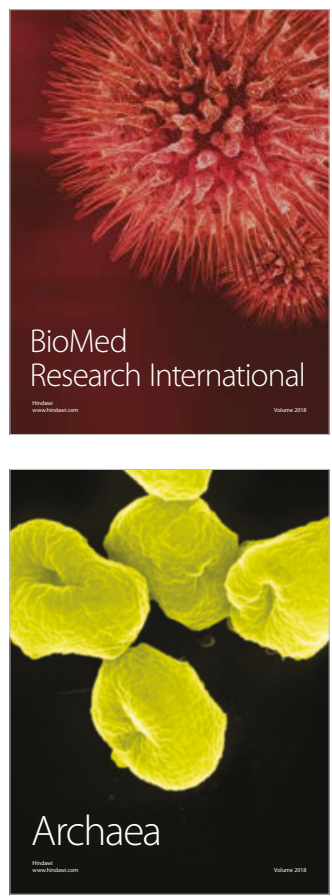